\title{
EVOLUÇÃO GEOLÓGICA DA PORÇÃO MERIDIONAL DA PROVÍNCIA BAUXITÍFERA DE PARAGOMINAS DURANTE O NEÓGENO/PLEISTOCENO (NOROESTE DA BACIA DO GRAJAÚ, NORDESTE DO PARÁ E EXTREMO OESTE DO MARANHÃO)
}

\author{
BASILE KOTSCHOUBEY ${ }^{1}$, WERNER TRUCKENBRODT ${ }^{2} \&$ J.M.C. CALAF ${ }^{3}$
}

\begin{abstract}
GEOLOGIC EVOLUTION OF THE SOUTHERN PORTION OF THE BAUXITE PROVINCE OF PARAGOMINAS DURING THE NEÓGENE/PLEISTOCENE (NORTHWESTERN OF THE GRAJAÚ BASIN, NORTHEASTERN PARÁ AND WESTERN EXTREMITY OF MARANHÃO) The surface geology of the southern Paragominas Bauxite Province, which lies in the northwestern Grajaú basin, essentially consists of two sedimentary-lateritic sequences. The oldest one is composed of siliciclastic deposits of the Cretaceous Itapecuru Group overlain by a lateritic/bauxitic mantle, which sustains the Paleogene Sul-Americana surface, and a clayey overburden - the Belterra Clay, whose top is marked by a fairly plane regional surface. The youngest sequence unconformably overlies the Itapecuru deposits in the low areas, which separate the plateaus of the Sul-Americana surface. The lower unit of this sequence consists of a reddish, poorly sorted and friable clayey sandstone up to $30 \mathrm{~m}$ thick, which contains dispersed laterite fragments and quartz pebbles, besides lateritic stone-lines. Although it is normally massive, the sandstone occasionally shows an incipient stratification. The reddish sandstone is overlain, in sharp contact, by a ferruginous duricrust up to $3 \mathrm{~m}$ thick, that sustains the Late Velhas surface of Neomiocene age. According to its degradation degree, the duricrust displays a columnar, blocky or nodular structure or a pisolitc facies. When completely degraded, the duricrust is transformed into a ferruginous stone-layer. Conglomeratic accumulations, composed of laterite blocks, pelitic fragments and strongly subordinate quartz pebbles locally occur, corresponding to colluvial deposits resulting from the dismantling of the oldest residual cover. The ferruginous duricrust is overlain in sharp contact by a homogeneous, yellowish sandy clay, up to $5 \mathrm{~m}$ thick, that contains minute laterite fragments. The surface which marks the top of this overburden is situated 60 to $80 \mathrm{~m}$ below the surface sustained by the Belterra Clay. The reddish sandstone represents a continental deposit originated by successive debris-flows and is correlated with the Pirabas and Barreiras Formations of NeoOligocene to Mesomiocene age. The ferruginous horizon, interpreted as a water-table laterite, was probably formed during the Neomiocene, while the clayey sandy overburden, comparable with the continental Pós-Barreiras sediments described to the north, in the Bragantina Platform, should be of Pliocene age.
\end{abstract}

Keywords: laterite, debri-flows, Neogene, Grajaú basin, Paragominas Bauxite Province, Late Velhas surface.

\begin{abstract}
Resumo O quadro geológico supérgeno da porção meridional da Província Bauxitífera de Paragominas, situada na parte noroeste da Bacia do Grajaú, consiste em duas seqüências sedimentares-lateríticas. A seqüência mais antiga é constituída por depósitos siliciclásticos cretáceos do Grupo Itapecuru, um manto laterítico/bauxítico, que sustenta a Superfície Sul-Americana do Paleógeno, e um capeamento argiloso, a Argila de Belterra, cujo topo é marcado por uma superfície plana regional. A seqüência mais jovem repousa em inconformidade sobre os depósitos Itapecuru nas áreas rebaixadas que separam os platôs lateríticos/bauxíticos. Esta seqüência é constituída, na base, por um arenito argiloso avermelhado, mal selecionado e friável, de até $30 \mathrm{~m}$ de espessura, que contém pequenos fragmentos dispersos de laterita ferruginosa e seixos de quartzo, além de linhas de pedras. Normalmente maciço, o arenito exibe localmente uma estratificação incipiente. Uma couraça ferruginosa de até $3 \mathrm{~m}$ de espessura repousa, em contato brusco, sobre o arenito argiloso, sustentando a Superfície Velhas tardia do Neomioceno. De acordo com o seu grau de degradação, a couraça exibe uma estrutura colunar, em blocos ou nódulos, ou uma fácies pisolítica, enquanto uma camada de pedras ferruginosa representa o estágio mais avançado do processo. Acumulações restritas de blocos de laterita, fragmentos de sedimentos pelíticos e seixos de quartzo fortemente subordinados correspondem a depósitos coluviais provenientes do desmantelamento da cobertura residual mais antiga. Sobre a couraça ferruginosa repousa um pacote argilo-arenoso, homogêneo, amarelado, de até $5 \mathrm{~m}$ de espessura, contendo diminutos fragmentos lateríticos. A superfície que marca o topo deste capeamento é fortemente dissecada e apresenta na região um desnível de 60 a 80 m em relação à superfície sustentada pela Argila de Belterra. $\mathrm{O}$ arenito da base da seqüência representa um depósito continental originado por sucessivos fluxos de detritos, cronocorrelato com as Formações Pirabas e Barreiras do final do Oligoceno ao Mesomioceno. A couraça ferruginosa, interpretada como laterita de lençol, ter-se-ia formado durante o Neomioceno, enquanto o capeamento argiloarenoso, comparável aos sedimentos continentais Pós-Barreiras descritos mais a norte, na Plataforma Bragantina, seria do Plioceno.
\end{abstract}

Palavras-chave: laterita, fluxos de detritos, Neógeno, Bacia do Grajaú, Província Bauxitífera de Paragominas, Superfície Velhas tardia.

INTRODUÇão Os depósitos cretáceos e cenozóicos, no nordeste do estado do Pará e oeste do estado do Maranhão, são objeto de estudos desde os anos 60 . No entanto, apenas a parte setentrional da Plataforma Bragantina e, em menor grau, a sua parte meridional, entre as cidades de Santa Maria do Pará e Ipixuna, foram por ora submetidas a investigações mais detalhadas (Sombroek 1966, Urdinínea 1977, Góes 1981, Ferreira \& Francisco 1988, Góes et al. 1990, Costa 1991, Kotschoubey et al. 1996, Costa

1 - Departamento de Geoquímica e Petrologia, Centro de Geociências, Universidade Federal do Pará, Belém, Pará, CEP: 66075-110. e-mail: basile@ufpa.br

2 - Departamento de Geologia, Centro de Geociências, Universidade Federal do Pará, Belém, Pará, CEP: 66075-110. e-mail: trucken@ufpa.br

3 - Curso de Pós-graduação em Geologia e Geoquímica, Centro de Geociências, Universidade Federal do Pará, Belém, Pará, CEP: 66075-110. 

do Grajaú, nordeste do Pará e extremo oeste do Maranhão)

\& Hasui 1997, Rossetti et al. 1989, 1990, Rossetti 2001). Permanece ainda pouco estudada a parte noroeste da Bacia do Grajaú (Góes \& Rossetti 2001), correspondendo à chamada Província Bauxitífera de Paragominas (Kotschoubey et al. 1997), onde só recentemente foram realizados alguns trabalhos de cunho estratigráfico, sedimentológico e geotectônico (Cavalcante 2000, Anaisse et al. 2001). Associadas aos depósitos cretáceos e cenozóicos, ocorrem duas coberturas lateríticas de distribuição regional. A mais antiga, do Paleógeno, foi bastante estudada nos últimos 25 anos (Kotschoubey \& Truckenbrodt 1981, Truckenbrodt \& Kotschoubey 1981, Truckenbrodt et al. 1982, Kotschoubey \& Truckenbrodt 1994, Truckenbrodt \& Kotschoubey 1994, Kotschoubey et al. 1987, 1989, 1997, Truckenbrodt et al. 1991, Horbe \& Costa 1999). No entanto, pouca atenção foi, por ora, dada às lateritas mais jovens e aos sedimentos associados na mesma região (Costa 1991, Calaf 2000, Rossetti 2001).

No presente trabalho procura-se, por um lado, caracterizar a sucessão sedimentar-laterítica do Neógeno-Pleistoceno na parte meridional da Província Bauxitífera de Paragominas (Fig. 1), e por outro, definir as condições físico-químicas e ambientais bem como os processos que controlaram a sua geração e posterior evolução.

O estudo, de caráter essencialmente estratigráfico com enfoque na evolução geomorfológica e paleoclimática da região em apreço, baseou-se essencialmente em levantamentos de campo e descrições de afloramentos e amostras. Análises petrográficas e por difração de raios $\mathrm{x}$ foram usadas apenas em apoio às observações em macro- e mesoescala.

CONTEXTOGEOLÓGICOREGIONAL AProvínciaBauxitífera de Paragominas, localizada na porção noroeste da Bacia do Grajaú (Fig. 1), apresenta na sua parte meridional depósitos do sistema estuarino-lagunar do Grupo Itapecuru do Cretáceo (Góes 1995,

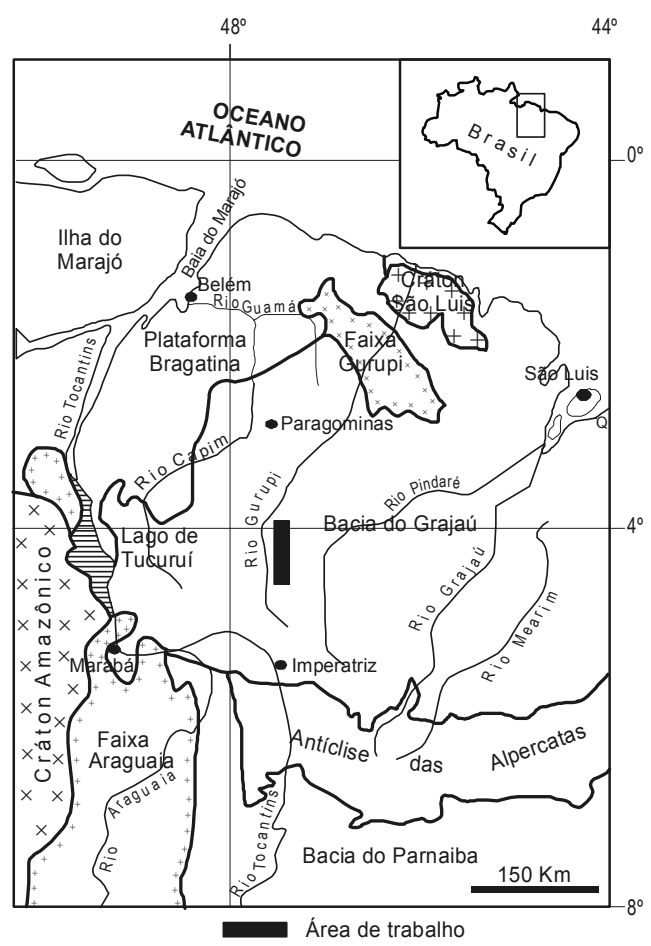

Figura 1 - Localização da área estudada no contexto geológico da Amazônia oriental.
Rossetti \& Truckenbrodt 1999, Anaisse et al. 2001). São arenitos friáveis com intercalações de argilitos e níveis de conglomerados com seixos de quartzo. Mais a norte, ocorrem os arenitos caulínicos e argilitos flúvio-estuarinos da Formação Ipixuna do Cretáceo Superior (Santos Jr. \& Rossetti 2002). Esses depósitos sustentam um espesso manto laterítico paleógeno, ferruginoso na porção sul da província em apreço e predominantemente aluminoso, bauxítico, nas suas partes central e setentrional (Kotschoubey \& Truckenbrodt 1981, Kotschoubey \& Truckenbrodt 1994, Kotschoubey et al. 1987, 1997).

Independente da natureza ferruginosa ou aluminosa, o manto de alteração é sobreposto, em contato brusco, pela Argila de Belterra, de até $20 \mathrm{~m}$ de espessura, com características de latossolo argiloso amarelado (Truckenbrodt \& Kotschoubey 1981, Truckenbrodt et al. 1991, Kotschoubey et al. 1997, Horbe \& Costa 1999).

Entre os platôs sustentados pela cobertura laterítica paleógena e seu capeamento argiloso, bem como nas zonas periféricas da província bauxitífera, ocorrem depósitos do Neógeno-?Pleistoceno com uma crosta ferruginosa intercalada. A norte da Província Bauxitífera de Paragominas, entre o rio Guamá e a cidade de Mãe do Rio, situada a cerca de $50 \mathrm{~km}$ a sul deste curso d'água, essa seqüência comporta, na sua parte inferior, depósitos carbonáticos e siliciclásticos, marinhos a costeiros, da Formação Pirabas do Oligoceno superior-Mioceno inferior (Ferreira 1982; Ferreira et al. 1984; Ferreira \& Francisco 1988) sobrepostos por argilitos laminados e arenitos argilosos da Formação Barreiras do Mioceno médio (Rossetti 2001). Mais a sul, ocorrem, na base da seqüência, arenitos argilosos, localmente conglomeráticos, e extensas lentes de argila semi-flint, interpretados por Kotschoubey et al. (1996) como depósitos provavelmente contemporâneos da Formação Pirabas. Os sedimentos Barreiras sobrepostos, exibindo fácies semelhantes às observadas mais a norte, foram reconhecidos até cerca de $25 \mathrm{~km}$ a sul de Vila Aurora (Kotschoubey et al. 1996) e assinalados nos arredores da cidade de Ipixuna por Rossetti (2001). A crosta ferruginosa ou seus produtos de degradação repousam, via de regra, sobre os depósitos Barreiras. Finalmente, o topo da seqüência consiste em areias e areias argilosas, em parte de origem eólica, denominadas sedimentos Pós-Barreiras (Sá 1969, Rossetti et al.1989), cuja idade seria plio-pleistocênica (ver Rossetti 2001).

ESBOÇOGEOMORFOLÓGICODAÁREA Naárea em estudo, distinguem-se duas superfícies (Fig. 2). A mais elevada é representada por platôs dissecados, bem individualizados, sustentados pela cobertura laterítica/bauxítica paleógena e por seu capeamento argiloso (Fig. 3). O topo dos platôs é extremamente plano e alcança uma altitude de aproximadamente $400 \mathrm{~m}$, na Serra do Gurupi, na parte meridional da área. Para norte a sua altitude diminui progressivamente, sendo de aproximadamente $280 \mathrm{~m}$ na parte sul do platô Chapadão, cerca de $30 \mathrm{~km}$ a norte de Açailândia, e 220 m nas proximidades de Ligação do Pará. O declive regional se suaviza em direção a Paragominas e a superfície alcança uma altitude entre 200 e $180 \mathrm{~m}$ próximo desta localidade. Observam-se também morros de topo abaulado, com altitudes ligeiramente inferiores às dos platôs mais próximos, resultantes da denudação e da remoção da cobertura laterítica-argilosa paleógena.

Testemunhos da superfície inferior ocorrem embutidos nos platôs supracitados. Trata-se fundamentalmente de relevos tabulares horizontais a suavemente inclinados em direção às drenagens atuais (rampas), bem como de morros com topos aplainados 
Basile Kotschoubey et al.

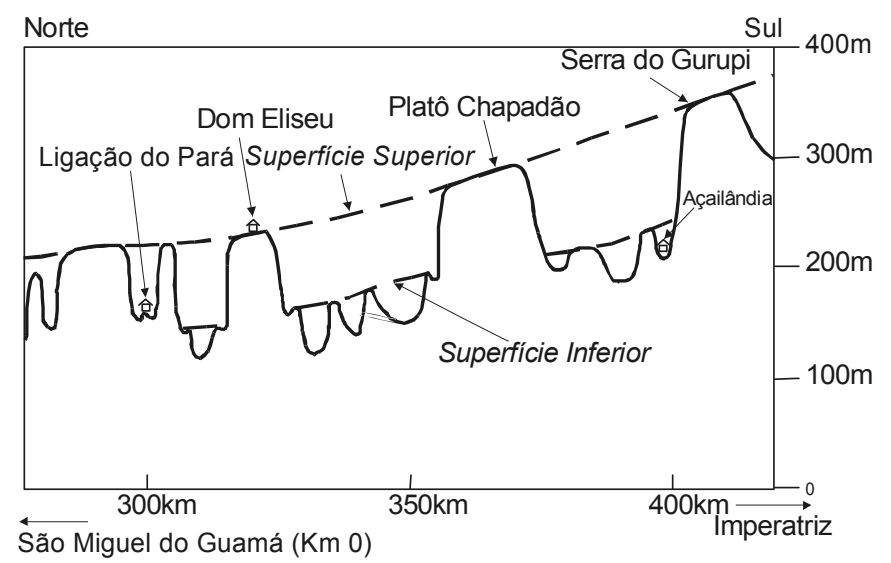

Figura 2 - Perfil topográfico norte-sul da área em estudo ressaltando as duas superficies regionais (modificado de Sombroek 1966).

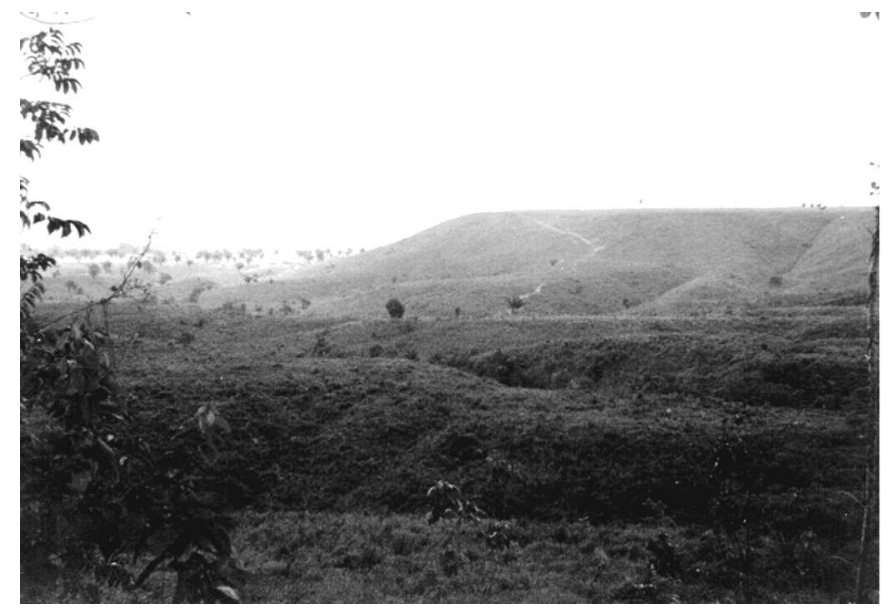

Figura 3 - Paisagem típica da parte meridional da Provincia Bauxitifera de Paragominas, destacando-se os platôs lateríticos/bauxíticos e, em primeiro plano, a superficie inferior fortemente ravinada.

e pequenas chapadas isoladas. Vales e ravinas dissecam fortemente esta superfície (Fig. 3). Estimada em cerca de $210 \mathrm{~m}$ a 15-20 $\mathrm{km}$ a norte da cidade de Açailândia, a sua altitude é de apenas 150 m a $65 \mathrm{~km}$ mais a norte, o que indica um leve declive, comparável àquele da superfície dominante (Sombroek 1966). Esta superfície mais baixa é, via de regra, sustentada por depósitos argilo-arenosos amarelados.

Em termos gerais, o desnível entre as duas superfícies é da ordem de $80 \mathrm{~m}$ nos setores mais meridionais, porém diminui progressivamente para norte até chegar a cerca de $60 \mathrm{~m}$ na região de Ligação do Pará. Os vales são mais encaixados na parte meridional que na parte setentrional da área enfocada.

SEQÜÊNCIASEDIMENTAR-LATERÍTICANEÓGENA Entre as cidades de Açailândia e Dom Eliseu, numa extensão de aproximadamente $80 \mathrm{~km}$ ao longo da rodovia federal BR 010 (BelémBrasília), bem como ao longo da rodovia BR 222, entre Dom Eliseu e Rondon do Pará (Fig. 4), foi efetuado um levantamento sistemático de todos os afloramentos expressivos de sedimentos e lateritas que sustentam a superfície inferior. Via de regra, os perfis comportam 3 unidades: a) um pacote sedimentar inferior, b) um horizonte laterítico e c) sedimentos superiores referidos como capeamento. As unidades sedimentares exibem poucas variações laterais, tanto composicionais como estruturais. Por sua vez, embora seja sempre ferruginoso, o manto laterítico apresenta variações faciológicas marcantes.

Pacote sedimentar inferior Esta unidade, que pode alcançar 30 $\mathrm{m}$ de espessura, consiste principalmente em arenito argiloso maciço, avermelhado, mal selecionado e friável. Embora o contato deste arenito com o Grupo Itapecuru não tenha sido encontrado ao

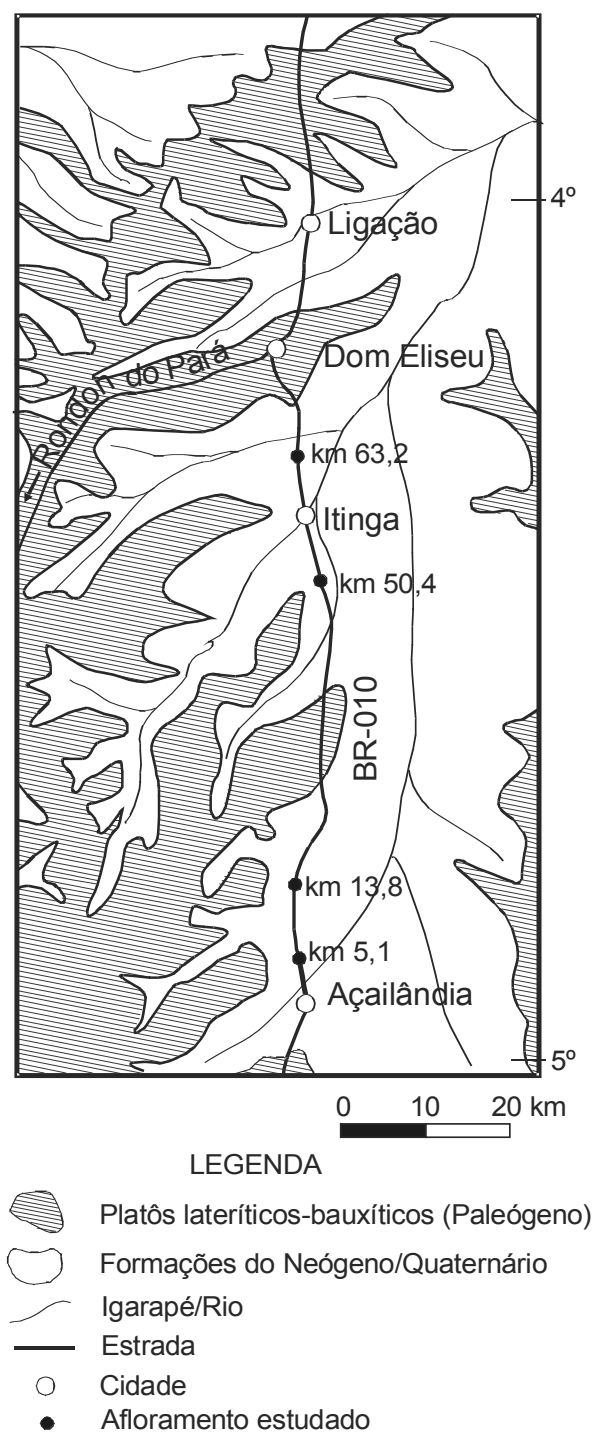

Figura 4 - Localização, ao longo da rodovia BR 010 (BelémBrasília), dos afloramentos-tipos das diferentes fácies lateríticas descritas no trabalho; Km 50,4: couraça laterítica pouco degradada, Km 18,3: couraça laterítica muito degradada, Km 63,2: camada de pedras oligomítica, Km 5,1: camada de pedras polimítica. 

do Grajaú, nordeste do Pará e extremo oeste do Maranhão)

longo da rodovia Belém-Brasilia, boas exposições dele foram observadas na rodovia Dom Eliseu-Rondon do Pará, a cerca de $7 \mathrm{~km}$ desta última localidade, onde o arenito avermelhado repousa em discordância sobre os depósitos cretáceos. $\mathrm{O}$ arenito é composto essencialmente de quartzo ( $60 \%$ em peso do total, em média), além de caulinita e oxi-hidróxido de ferro. Ocorrem também fragmentos de tamanho milimétrico de laterita ferruginosa e seixos de quartzo. Os principais minerais pesados transparentes são estaurolita, zircão, turmalina, rutilo e anatásio. Em alguns afloramentos, foram observadas linhas de pedras ou delgadas camadas de pedras compostas de fragmentos centimétricos, angulosos a arredondados de laterita ferruginosa, intercalados no arenito avermelhado. Estas formações exibem feições irregulares, algo onduladas e geralmente convexas para cima. Com espessura centimétrica a decimétrica, elas podem passar bruscamente a bolsões de dimensões métricas. Linhas de pedras lateríticas descontínuas acompanham normalmente as camadas de pedras. Em certos locais, no topo do pacote arenítico, linhas de pedras lateríticas, finos níveis goethíticos litificados e pequenas lentes fragmentadas de argila caulínica esbranquiçada de tipo semi-flint estão intercalados no pacote arenítico, conferindo-lhe uma estratificação incipiente.

Horizonte laterítico Para uma análise mais detalhada deste horizonte, foram escolhidos quatro perfis representativos mostrando fácies diferentes (Fig. 4). Assim, a 50,4 e 18,3 km a norte de Açailândia, o horizonte laterítico consiste numa couraça ferruginosa in situ, fracamente a fortemente degradada, respectivamente. No km 63,2, entre as cidades de Itinga e Dom Eliseu, está exposta uma camada de pedras oligomítica exibindo sinais de dissecação e ravinamento. Finalmente, a 5,1 km a norte de Açailândia, aflora amplamente uma camada de pedras de composição complexa. Via de regra, os contatos do horizonte laterítico com o substrato e o capeamento são bruscos.

COURAÇA LATERÍTICA IN SITU POUCO DEGRADADA A couraça ferruginosa comporta dois níveis distintos (Fig. 5). O nível inferior, de até $2 \mathrm{~m}$ de espessura, exibe uma estrutura colunar bem expressa. As colunas lateríticas, levemente inclinadas por efeito de rastejo, são revestidas por cutãs goethíticas. A laterita consiste essencialmente em uma matriz criptocristalina, composta de hematita, goethita e caulinita, envolvendo quantidade variável de grãos de quartzo submilimétricos. A couraça exibe geralmente uma porosidade notável devida à dissolução de parte destes grãos. Cutãs goethíticas, zonas porosas e friáveis contendo apenas goethita, e concreções evoluindo para uma textura pisolítica são testemunhos de intensa circulação de soluções bem como da mobilização e redistribuição do ferro na couraça laterítica. Utilizando-se o método de Solymar (1969), foi identificada goethita aluminosa contendo até $18 \%$ de $\mathrm{AlOOH}$ nas cutãs e nas zonas porosas e friáveis, essencialmente goethíticas. Os túbulos intercolunares são preenchidos por argila composta de caulinita e oxi-hidróxido de ferro e contendo diminutos grãos de quartzo. $\mathrm{Na}$ base deste nível, as colunas mostram sinais de fragmentação e degradação para nódulos e grânulos.

O nível superior, de até $1 \mathrm{~m}$ de espessura, é composto de fragmentos lateríticos angulosos a sub-arredondados de até $5 \mathrm{~cm}$ de comprimento, imersos em matriz argilosa, avermelhada, pouco abundante (Fig. 6). Esses fragmentos exibem, internamente, uma textura pisolítica densa. Para cima, os fragmentos diminuem progressivamente em tamanho e passam a um cascalho ferruginoso imerso em matriz argilosa.

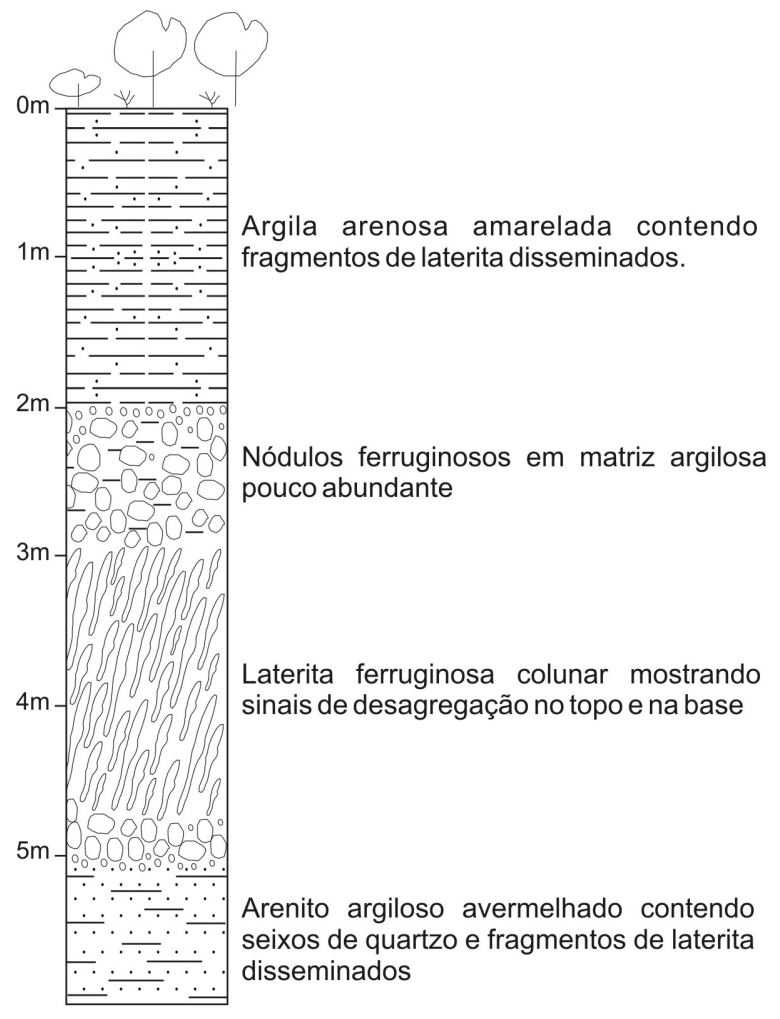

Figura 5 - Perfil esquemático da seqüência sedimentarlaterítica do $\mathrm{km}$ 50,4, comportando uma couraça ferruginosa pouco degradada.

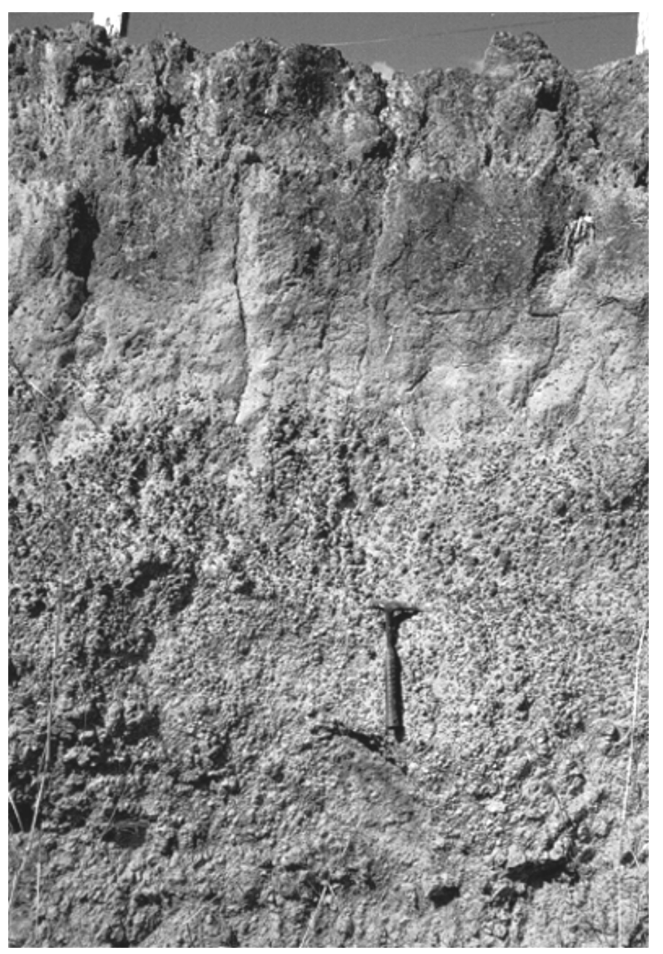

Figura 6 - Parte superior, degradada e fragmentada, da couraça laterítica do perfil do $\mathrm{km} \mathrm{50,4.} \mathrm{Observar} \mathrm{a} \mathrm{estrutura}$ colunar da couraça na parte inferior da foto. 
COURACA LATERÍTICA IN SITU FORTEMENTE DEGRADA-

$D A$ O horizonte laterítico tem espessura média de cerca de $2 \mathrm{~m}$ (Fig. 7). O seu limite superior é ondulado e irregular, e contrasta com o inferior quase plano, sub-horizontal. A parte inferior do nível ferruginoso, com espessura de até 1,5 m, é constituída de fragmentos de laterita densamente empacotados, com pouca matriz argilosa. Os fragmentos, na maioria angulosos, se encaixam uns nos outros. Para cima, a laterita fragmentada passa para um cascalho com grãos de até $3 \mathrm{~cm}$ de comprimento, envoltos em matriz argilosa mais abundante. No topo da couraça, o cascalho dá progressivamente lugar a pisólitos sobre os quais repousa o capeamento. Localizadamente, blocos arredondados, decimétricos a métricos, de laterita maciça com feições colunares subverticais incipientes estão envoltos na laterita fragmentada ou no cascalho laterítico, com os quais apresentam contatos bruscos (Fig. 8).

CAMADA DE PEDRAS OLIGOMÍTICA A 63,2 km a norte de Açailândia, numa extensão de cerca de $300 \mathrm{~m}$, aflora uma camada de pedras em forma de guirlanda de lentes de até 1,5 m de espessura, interligadas através de linhas de pedras (Figs. 9 e 10). Via de regra, o limite superior das lentes é convexo para cima, enquanto o seu limite inferior é plano e sub-horizontal. Uma leve inflexão para baixo deste limite se observa somente nas extremidades das lentes, coincidindo com o adelgaçamento da camada de pedras. A camada de pedras é composta de fragmentos de laterita ferruginosa arredondados a angulosos, de até $10 \mathrm{~cm}$ de comprimento. A matriz argilosa, pouco abundante, consiste essencialmente em caulinita, goethita e diminutos grãos de quartzo subordinados.

CAMADA DE PEDRAS POLIMÍTICA Este horizonte, de cerca de 3,5 $\mathrm{m}$ de espessura, é composto principalmente de fragmentos arredondados a angulosos de laterita ferruginosa, cavernosa, exi-

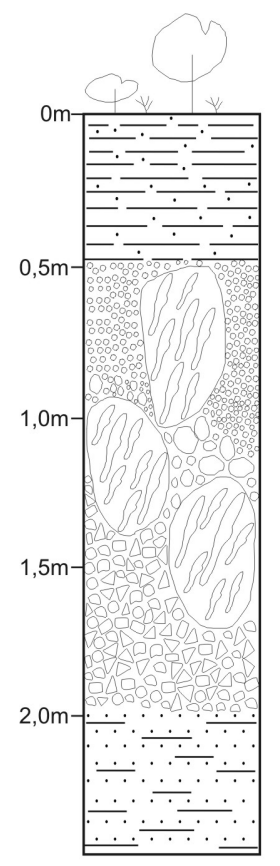

Argila arenosa amarelada com fragmentos de laterita disseminados

Blocos de laterita colunar envoltos em cascalho ferruginoso com matriz argilosa

Blocos de laterita colunar em horizonte de fragmentos ferruginosos angulosos

Figura 7 - Perfil esquemático da seqüência sedimentarlaterítica do $\mathrm{km}$ 18,3 com horizonte lateritico fortemente degradado.

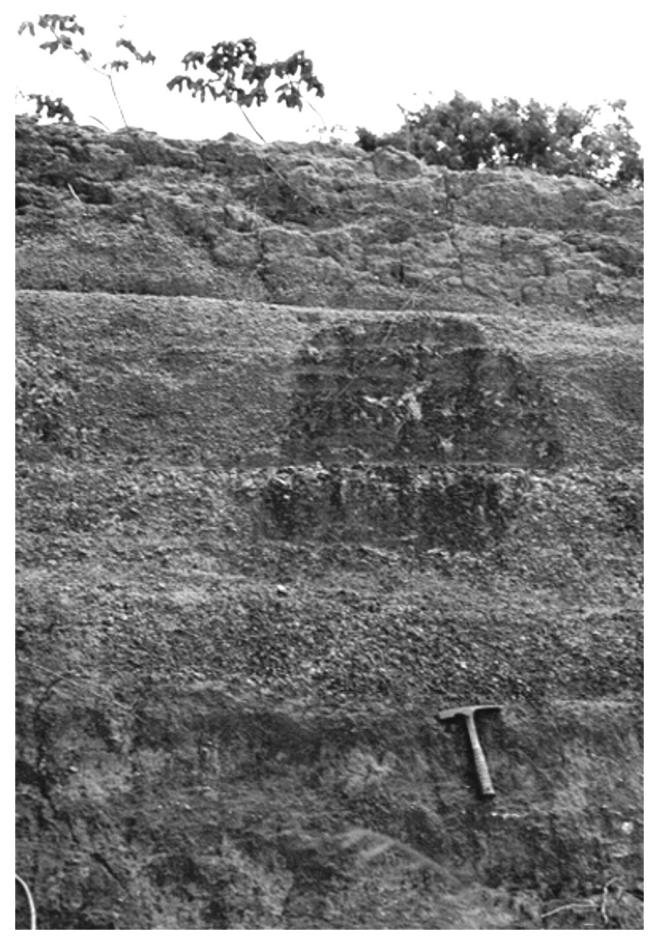

Figura 8-Couraça ferruginosa fortemente degradada do perfil do $\mathrm{km} \mathrm{18,3.} \mathrm{Notar} \mathrm{o} \mathrm{bloco} \mathrm{de} \mathrm{laterita} \mathrm{com} \mathrm{estrutura} \mathrm{colunar}$ envolto em laterita altamente fragmentada.

bindo feições escoriáceas e concreções internas. Esta laterita é semelhante àquela que constitui a couraça ferruginosa do Paleógeno observada na Serra do Gurupi próxima. Dispersos aleatoriamente entre os fragmentos ferruginosos, encontram-se seixos de quartzo e de argila esbranquiçada de tipo semi-flint, bem como raros seixos de argilito marrom. Este depósito exibe uma estratificação plano-paralela incipiente, sublinhada por uma seleção gradativa discreta dos fragmentos de laterita (Fig.11). Uma matriz composta de grãos de quartzo e diminutos fragmentos de argilito vermelho-tijolo cimentados por oxi-hidróxido de ferro envolve em parte os fragmentos de laterita e os seixos. Os espaços interclastos são preenchidos por argila caulínica contendo goethita e finos grãos de quartzo subordinados.

Capeamento argilo-arenoso Acobertura do horizonte laterítico e das camadas de pedras consiste em um latossolo argilo-arenoso de coloração amarelada, cuja espessura ao longo da rodovia BelémBrasília alcança $5 \mathrm{~m}$. Contém, em média, $40 \%$ em peso de grãos de quartzo, além de caulinita, goethita, hematita e grânulos de laterita. Como minerais pesados transparentes, foram identificados estaurolita, turmalina, zircão, rutilo e anatásio. Camadas de pedras de até $20 \mathrm{~cm}$ de espessura, lenticulares ou contínuas, bem como linhas de pedras ocorrem comumente próximo à base deste capeamento. Um bom exemplo de tais intercalações de fragmentos lateríticos densamente empacotados é observado no $\mathrm{km} 5,1$.

DISCUSSÃO As formações aflorantes na porção meridional da Província Bauxitífera de Paragominas constituem duas seqüências sedimentares-lateríticas, que sustentam superfícies regionais e são separadas por uma inconformidade maior (Fig. 12). A seqüência mais antiga domina topograficamente a região e é profunda- 

do Grajaú, nordeste do Pará e extremo oeste do Maranhão)

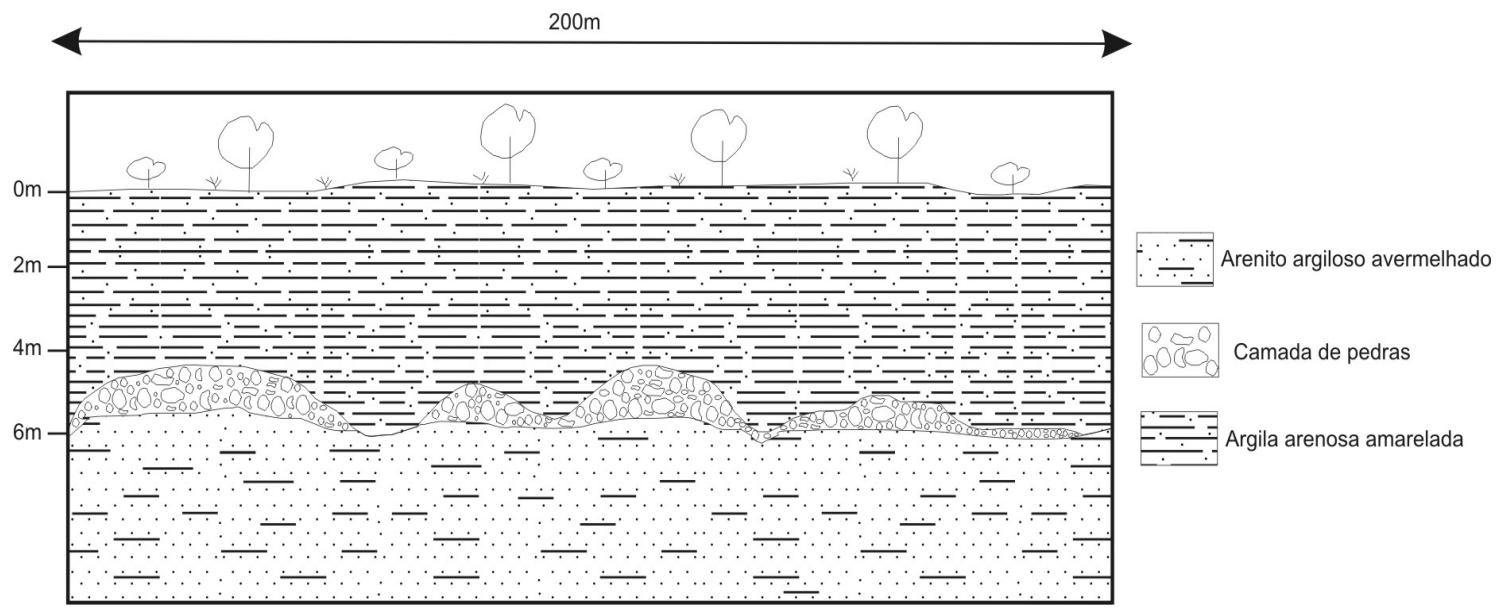

Figura 9 - Perfil lateral esquemático da seqüencia laterítica-sedimentar com camada de pedras exposta em corte da rodovia BR-010 (Belém-Brasília) a 63,2 km a norte de Açailândia.

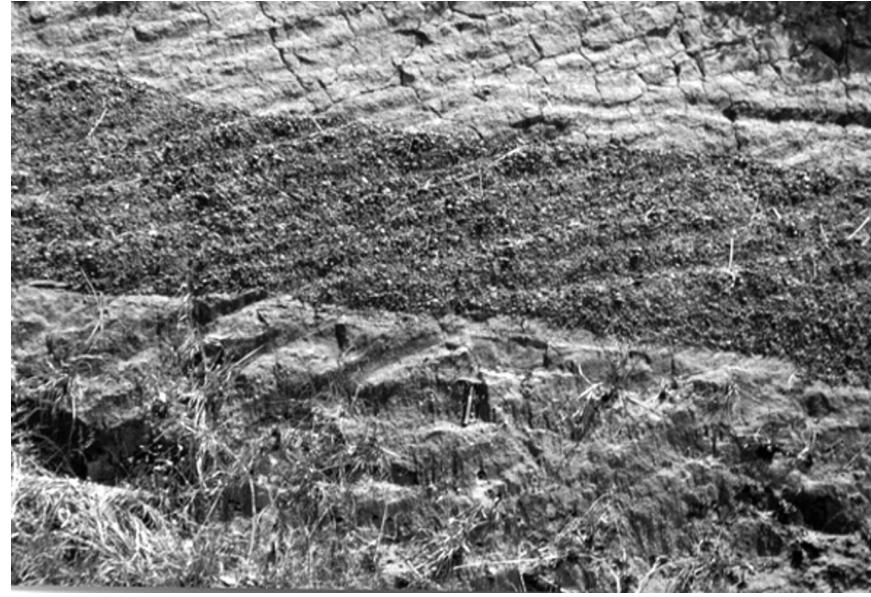

Figura 10-Camada de pedras do km 63,2 mostrando contatos bruscos com o arenito avermelhado sotoposto e o capeamento argilo-arenoso.

mente dissecada por amplos vales. A seqüência mais jovem, com superfície situada, em média, $70 \mathrm{~m}$ abaixo da superfície mais antiga, é constituida por três unidades: um pacote de arenito argiloso avermelhado, um manto laterítico e um capeamento argilo-arenoso amarelado. $\mathrm{O}$ arenito argiloso se distingue fortemente das formações depositadas em ambiente de mar aberto ou costeiro na Plataforma Bragantina durante o Neógeno. Exibe poucas variações texturais e composicionais, é mal selecionado, pobremente estratificado e contém fragmentos lateríticos e esparsos seixos de quartzo. Tais características sugerem tratar-se de produto de degradação e desmantelamento de depósitos Itapecuru e da cobertura laterítica paleógena, transportado por processos gravitacionais. A ausência de vestígios de bauxita nestes sedimentos é provavelmente devida à sua rápida silicificação e transformação em produtos caulínicos em ambiente saturado, apresentando uma lenta renovação das águas e elevada atividade de $\mathrm{H}_{4} \mathrm{SiO}_{4}$. A existência de linhas de pedras e bolsões de fragmentos lateríticos mostra que os sedimentos se depositaram em várias etapas, formando um sistema complexo de leques coalescentes.

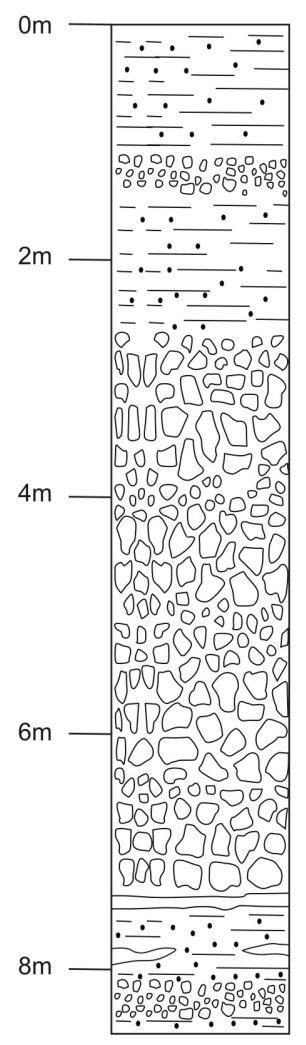

Argila arenosa amarelada com diminutos fragmentos de laterita disseminados. Comporta uma camada de pedras de cerca de $20 \mathrm{~cm}$ de espessura formada por pequenos

Camada de pedras composta de fragmentos e nódulos lateríticos, mostrando um incipiente acamamento. Contém alguns seixos de quartzo, de argila "flint" e raros fragmentos de rocha pelítica. Os

Arenito argiloso avermelhado contendo fragmentos lateríticos disseminados, finos níveis de plaquetas ferruginosas e de argila

Figura 11 - Perfil esquemático da seqüência sedimentarlaterítica do $\mathrm{km} \mathrm{5,1}$ comportando uma camada de pedras polimítica.

Essas acumulações de fragmentos lateríticos correspondem a paleopavimentos, depósitos coluviais de sopé e preenchimentos de canais, individualizados sob efeito da ação mecânica seletiva das águas de escoamento superficial, que levou à remoção das frações mais finas dos depósitos originais. A discreta laminação sublinhada pelas finas lentes de argila semi-flint e níveis limoníticos litificados sugere, no entanto, que a sedimentação ocorreu 
Oligoceno

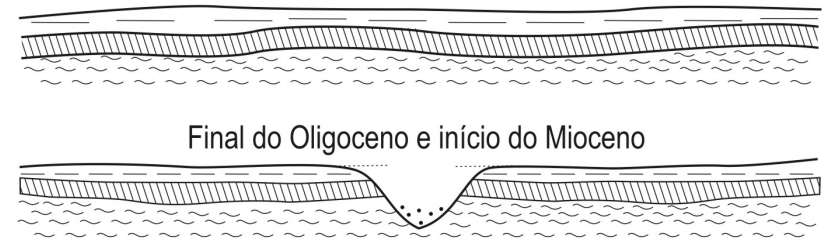

Eo/Mesomioceno

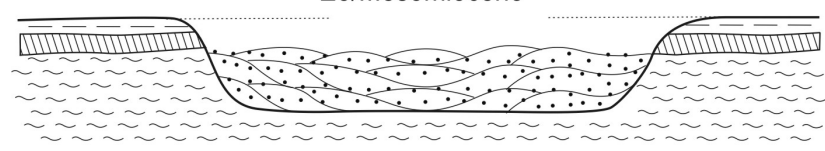

Neomioceno

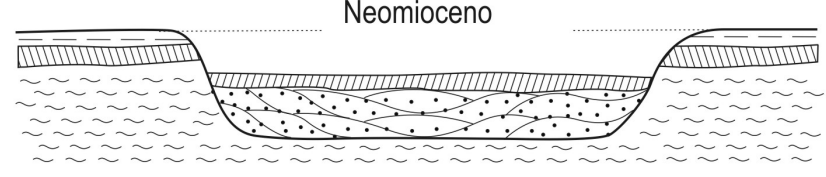

Final do Mioceno e início do Plioceno

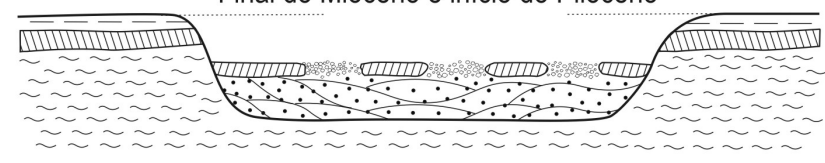

Plioceno
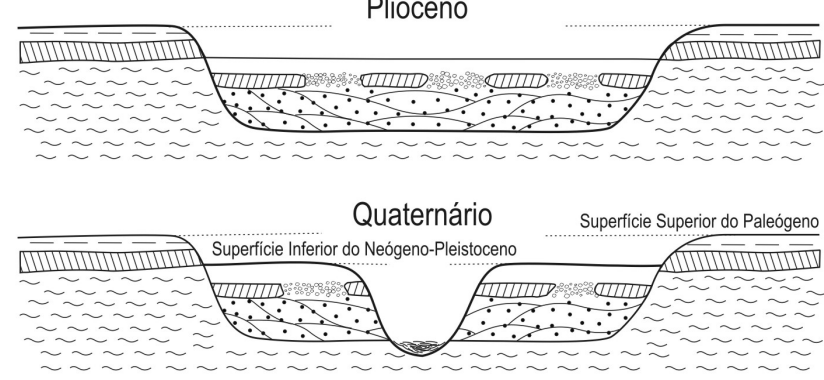

Argila de Belterra

Sequência lateritica-bauxítica

Grupo Itapecurú

Argila arenosa amarelada

Couraça ferruginosa/camada de pedras

$\because \because$ Arenito argiloso avermelhado

Aluviões recentes

Figura 12 - Evolução geológica esquemática do Oligoceno até o Quaternário da porção meridional da Província Bauxitífera de Paragominas. Notar as duas superficies regionais sustentadas pelas seqüências e a inconformidadeprovável Superfície Velhas antiga - que separa estas últimas.

episodicamente em condições calmas de poças d'água.

A unidade intermediária, que consiste em um horizonte ferruginoso litificado, exibe um grau variável de degradação. As porções mais preservadas deste horizonte indicam que se tratava originalmente de uma couraça maciça, composta de goethita e hematita cimentando sedimentos areno-argilosos semelhantes aos da unidade sotoposta. A ausência de um horizonte saprolítico ou de uma zona desferrificada ou zona pálida sugere que a crosta ferruginosa formou-se essencialmente através de aportes laterais de ferro por águas subterrâneas, sendo, portanto, de tipo laterita de lençol. A oscilação sazonal do nível freático, característica de clima tropical contrastado, parece ter contribuído sobretudo à precipitação do oxi-hidróxido de ferro. Acredita-se que o ferro foi herdado em sua maior parte de acumulações ferruginosas mais antigas, situadas em posição mais elevada topograficamente. Assim, o manto laterítico paleógeno é a fonte mais provável do ferro, cuja mobilização e transporte devem ter ocorrido na forma de complexos organo-metálicos, solúveis e estáveis em condições oxidantes, em clima e ambiente permitindo, por um lado, a produção de abundante matéria orgânica e, por outro, a sustentação de fluxo de águas subterrâneas. Após a precipitação do oxi-hidróxido de ferro e a cimentação dos sedimentos areno-argilosos, parte dos grãos de quartzo foi dissolvida, conferindo à crosta uma porosidade notável.

O estágio inicial da degradação da crosta ferruginosa é marcado pelo aparecimento de feições colunares subverticais, originadas pela individualização de cavidades tubulares, revestidas por cutãs goethíticas e hoje preenchidas por argila proveniente do capeamento. Um estágio mais avançado da degradação se traduz pela fragmentação da crosta ferruginosa colunar tanto na sua parte inferior como no topo. Finalmente, a fragmentação pode tomar conta da crosta ferruginosa em toda a sua espessura, permanecendo ou não vestígios da estruturação colunar.

Esses diferentes estágios de degradação da crosta ferruginosa são todos resultados de um mesmo processo complexo, que atua até agora e envolve a biota, principalmente a ação das raizes, a matéria orgânica e seus diversos produtos de decomposição e as soluções percolantes. A liberação de ions $\mathrm{H}^{+}$pelas raizes e a sua fixação pelos argilominerais, bem como a presença de ácidos carbônico e orgânicos contribuiram à acidificação do meio, enquanto a presença de radicais orgânicos levou à formação de complexos organo-metálicos solúveis, importantes na mobilização e transferência de $\mathrm{Fe}, \mathrm{Al}$ e Si. A saturação periódica de porções da crosta, tais como a base do horizonte ferruginoso e as cavidades tubulares, e a conseqüente estagnação das águas favoreceram a redução e dissolução de parte do ferro, acelerando a degradação da crosta. A remobilização de $\mathrm{Fe}$, seguida da sua reprecipitação na forma de oxi-hidróxido, reduziu a porosidade original e modificou a textura da laterita. No topo do horizonte ferruginoso colunar, a degradação provavelmente prosseguiu após a deposição do capeamento argilo-arenoso, levando à formação de um cascalho avermelhado, observado em algumas exposições.

Acentuando-se a degradação, formou-se uma camada de fragmentos densamente empacotados, encaixados uns nos outros, com pouca matriz argilosa nos restritos espaços intersticiais. A mobilização do ferro nestes limitados ambientes redutores e ácidos permitiu a sua lixiviação ao longo de fissuras ou túbulos, deixando in situ produtos residuais argilosos, porosos e altamente friáveis, que foram posteriormente removidos mecanicamente pelas águas percolantes. Deste modo, o tamanho das fissuras e dos túbulos foi aumentando progressivamente, facilitando a iluviação e o preenchimento destes espaços pela argila do próprio capeamento. A retenção da água por estes depósitos argilosos e a saturação periódica destes permitiu o prosseguimento da dissolução do ferro e do processo de degradação química.

Os blocos de laterita exibindo estrutura colunar subvertical, que ocorrem em meio a acumulações de fragmentos menores, são vestígios da crosta poupados pela degradação mais avançada e praticamente não deslocados pelos movimentos de acomodação da seqüência sedimentar-laterítica. 
Com o prosseguimento da degradação da crosta, os fragmentos lateríticos tornaram-se menores e mais arredondados na porção superior do horizonte ferruginoso. Parte da caulinita contida na laterita sofreu dissolução incongruente. A sílica liberada foi lixiviada, enquanto a alumina permaneceu in situ ou sofreu um deslocamento mínimo, sendo incorporada na goethita neoformada que contém até $18 \%$ de $\mathrm{AlOOH}$. A remoção pelas águas de escoamento superficial de grande parte da matriz argilosa originada pela degradação resultou em uma camada de grânulos lateríticos exibindo arcabouço fechado. Em caso de fragmentação total do horizonte laterítico, torna-se difícil determinar se houve ou não retrabalhamento físico. Tal é o caso da camada de pedras do perfil do km 63,2 que, por outro lado, parece ter sofrido dissecação e ravinamento.

A heterogeneidade composicional da crosta detritica do $\mathrm{km}$ 5,1 e a medíocre seleção dos fragmentos sugerem que se trata de depósito coluvial (couraça coluvial de sopé?). A presença de matriz arenosa cimentada por oxi-hidróxido de ferro na camada de fragmentos lateríticos indica que houve ferruginização parcial desta formação, antes do capeamento argilo-arenoso se depositar.

Os sedimentos argilo-arenosos maciços, mal selecionados e contendo diminutos fragmentos lateríticos, sobrepostos à crosta ferruginosa ou à camada de pedras derivada desta, foram depositados a partir de fluxos gravitacionais de produtos siliciclásticos, provavelmente gerados pelo retrabalhamento tanto dos sedimentos Itapecuru como de todas as formações lateríticas e/ou bauxíticas e sedimentares mais recentes. Este pacote apresenta a mesma textura e composição mineralógica em todos os perfís estudados, assemelhando-se aos sedimentos Pós-Barreiras (Sá 1969; Rossetti et al. 1989) que ocorrem a norte de Paragominas (Kotschoubey et al. 1996).

EVOLUÇÃO REGIONAL Durante o Neógeno, a evolução geológica na Amazônia Oriental foi controlada essencialmente por oscilações do nível do mar, provocadas por variações climáticas globais e episódicos movimentos tectônicos de amplitude regional, resultantes da reativação do tectonismo nesse período (Tardy \& Roquin 1998, Rossetti 2001). Após as primeiras grandes colisões do final do Eoceno-Oligoceno na margem ocidental do continente sul-americano, houve uma forte diminuição da atividade tectônica até o Mesomioceno, quando intensos movimentos marcaram o início da edificação da cadeia andina (Tardy \& Roquin 1998). Na Amazônia Oriental, a orogênese andina refletiu-se na forma de soerguimentos e basculamentos regionais. No final do Mesomioceno-início do Neomioceno, ocorreu provavelmente o alçamento de toda a região em apreço. Daí em diante, a atividade tectônica prosseguiu com intensidade variável no domínio andino, havendo poucas informações sobre o seu impacto na Amazônia Oriental.

As oscilações do nível do mar durante o Neógeno (Krook 1979, Rossetti 2000, 2001) afetaram também, embora com menor intensidade e de maneira indireta, as regiões mais continentais. No entanto, enquanto os depósitos costeiros e marinhos deste período foram estudados em detalhe na Amazônia Oriental Brasileira e, em particular, no nordeste do Pará (Urdinínea 1977, Góes \& Truckenbrodt 1980, Ferreira et al. 1984, Arai et al. 1988, Fernandes 1988, Ferreira \& Francisco 1988, Rossetti et al. 1989, 1990, Góes et al. 1990, Leite et al. 1997, Rossetti 2001), há ainda poucas informações sobre os depósitos sedimentares continentais e formações lateríticas nas regiões mais distantes da zona litorânea (Costa 1991, Calaf et al. 1999ab, Calaf 2000). Por outro lado, foram realizadas, durante a última década e em diversas regiões da Amazônia Oriental, datações de crostas lateríticas. Utilizando os métodos ${ }^{40} \mathrm{Ar} /$ ${ }^{39} \mathrm{Ar} \mathrm{e}{ }^{40} \mathrm{~K} /{ }^{40} \mathrm{Ar}$ na tentativa de datação de lateritas manganesíferas da região de Carajás, Vasconcelos et al. $(1992,1994)$ identificaram, no Neógeno, dois períodos de lateritização: no Eomioceno e no Mesomioceno, aos quais acrescentaram uma derradeira fase no início do Pleistoceno. Mais recentemente, através de métodos paleomagnéticos, Théveniaut \& Freyssinet (1999) e Théveniaut \& Freyssinet (2002) definiram na Guiana Francesa e no Suriname, durante o Neógeno, dois períodos de lateritização, ambos no Mioceno, sendo o segundo situado mais precisamente no Neomioceno.

No Oligoceno Superior, um forte rebaixamento do nível relativo do mar, provocado pelo resfriamento do clima global (Tardy \& Roquin 1998), resultou em profunda dissecação da seqüência cretácea-paleógena e em individualização de extensos platôs, enquanto um clima seco predominava na Amazônia (Krook 1979). Os primeiros movimentos tectônicos relacionados à estruturação da cadeia andina, ocorridos no Eoceno e Oligoceno, tiveram provavelmente efeitos tardios sobre amplas porções da Amazônia Oriental, resultando em soerguimentos regionais. Estes tiveram certamente também um papel importante no processo erosivo e nas mudanças na paisagem. A norte da atual Província Bauxitífera de Paragominas, a quase total destruição do manto laterítico/bauxítico levou à individualização da Plataforma Bragantina (Urdinínea 1977) e à formação de uma superfície, provavelmente a Superfície Velhas antiga ou Early Velhas Surface (King 1967). Com o reaquecimento progressivo do clima global, esta região baixa e aplainada experimentou, no final do Oligoceno-Eomioceno, uma transgressão marinha com a deposição da Formação Pirabas e da parte inferior da Formação Barreiras (Urdinínea 1977, Rossetti 2001). Após um episódio regressivo no final do Eomioceno/início do Mesomioceno, indicado pela inconformidade 2 de Rossetti (2001), o ambiente costeiro voltou, marcado pela deposição dos sedimentos das partes média e superior da Formação Barreiras (Rossetti 2001). O Neomioceno, por sua vez, foi marcado por uma regressão marinha geral e pela predominância de condições tropicais úmidas, que permitiram a formação de uma couraça laterítica ferruginosa sustentando uma superfície regional, considerada como sendo a Superfície Velhas tardia ou Late Velhas Surface de King (1967). Em seguida, iniciou-se um período de transgressões e regressões alternadas em condições provavelmente mais secas (Tardy \& Roquin 1998). Neste período, que corresponderia ao Plio-Pleistoceno, depositos areno-argilosos continentais, referidos como sedimentos Pós-Barreiras, se acumularam sobre a couraça laterítica (Rossetti 2001).

$\mathrm{Na}$ parte meridional da atual Província Bauxitífera de Paragominas, o rebaixamento do nível de base no Oligoceno Superior, devido, provavelmente, a um soerguimento tectônico mais expressivo, provocou uma incisão da superfície paleógena mais profunda que na porção norte da província. A formação de vales profundos e encaixados foi seguida pelo alargamento progressivo desses últimos e a individualização de amplos platôs (Fig. 12).

Com a elevação do nível de base, a erosão enfraqueceu e processos deposicionais se impuseram. Ocorreu, então, o entulhamento/assoreamento dos vales por depósitos areno-argilosos contendo fragmentos lateríticos e pequenos seixos de quartzo gerados por fluxos de detritos e derivados sobretudo dos sedimentos Itapecuru e do capeamento argiloso, sendo muito subordinada a contribuição da crosta laterítica/bauxítica (Fig. 12). Localmente, nos sopés dos platôs, formaram-se couraças coluviais, de 
composição heterogênea, resultando principalmente do desmantelamento da couraça laterítica paleógena e de camadas argilíticas do Grupo Itapecuru, da acumulação e da posterior cimentação de fragmentos dessas formações. Todos esses depósitos são correlacionados com as Formações Pirabas e Barreiras. Embora as condições chuvosas tenham predominado no Eo- e Mesomioceno, um clima mais seco instalou-se temporariamente em várias ocasiões, permitindo a formação de paleopavimentos e outras acumulações superficiais de detritos lateríticos, hoje inseridos nesses sedimentos.

As condições tropicais úmidas porém contrastadas que marcaram o Neomioceno (Tardy \& Roquin, 1998), causaram a formação de uma couraça ferruginosa sobre os arenitos argilosos (Fig. 12). Com a progressiva mudança para um clima tropical semi-úmido e a provável evolução da floresta para uma cobertura vegetal de tipo savana ou cerrado, a couraça ferruginosa exposta ou subaflorante sofreu um grau variável de degradação que, em certas áreas, levou à sua completa transformação em camada de pedras. No Plioceno, em condições climáticas mais secas, houve reativação dos processos erosivos. Os depósitos do Cretáceo expostos nas margens dos vales, as lateritas/bauxitas paleógenas e o seu capeamento argiloso, bem como os sedimentos e lateritas ferruginosas do Mioceno, foram fragmentados, retrabalhados e redistribuídos. Resultou, assim, a acumulação, sobre a crosta ferruginosa ou os produtos de sua degradação (camadas de pedras), de sedimentos areno-argilosos com pequenos fragmentos lateríticos, correlacionáveis com os sedimentos Pós-Barreiras que ocorrem a norte de Paragominas (Sá 1969; Rossetti et al. 1989, Kotschoubey et al. 1996) (Fig. 12).

Posteriormente, no Pleistoceno, em resposta a um novo soerguimento regional ou uma regressão marinha de maior amplitude, ocorreram um rebaixamento do nível de base, a retomada dos processos erosivos, a dissecação da superfície sustentada pela seqüência sedimentar-laterítica do Neógeno e a instalação da rede de drenagem atual (Fig. 12).

CONCLUSÃO O desenvolvimento do quadro sedimentarlaterítico do Neógeno, na porção noroeste da Bacia do Grajaú, foi precedido, no Oligoceno superior, por um evento erosivo de importância maior, causado provavelmente tanto pelo resfriamento do clima global, como por movimentos epirogénicos, reflexos do início da orogênese andina na Amazônia brasileira. A erosão afetou profundamente a cobertura laterítica/bauxítica regional e seu capeamento argiloso - a Argila de Belterra - formados durante o Paleógeno às custas dos sedimentos flúvio-estuarinos do Grupo Itapecuru (Cretáceo), dissecando a Superfície Sul-Americana e levando ao desenvolvimento de amplos vales e à individualização de extensos platôs. A superfície resultante desta fase erosiva seria a Superfície Velhas antiga. Com a volta de condições climáticas mais quentes e úmidas e de um relativo equilíbrio tectônico, os vales sofreram, do final do Oligoceno até o final do Mesomioceno, um entulhamento por produtos de degradação e desmantelamento do Grupo Itapecuru, do manto laterítico/bauxítico e do seu capeamento. Acredita-se que esses depósitos continentais foram contemporâneos dos sedimentos marinhos a costeiros Pirabas e Barreiras da Plataforma Bragantina. Durante o Neomioceno, sob clima tropical úmido, formou-se uma crosta ferruginosa de tipo laterita de lençol, sustentando uma superfície regional, provavelmente à Superfície Velhas tardia. Com a mudança do clima para um regime de tipo tropical semi-úmido, a crosta ferruginosa sofreu intensa degradação e até transformação em espessa camada de pedras. No Plioceno, em condições de clima mais seco, tornaram a predominar os processos erosivos, o que resultou em acumulação de sedimentos siliciclásticos, correlacionáveis com os sedimentos Pós-Barreiras reconhecidos mais a norte, na região Bragantina. No Pleistoceno, um novo rebaixamento regional do nível de base provocou a incisão da seqüência sedimentar/laterítica do Neógeno e a instalação da rede de drenagem atual.

Agradecimentos Ao Curso de Pós-Graduação em Geologia e Geoquímica do Centro de Geociências da Universidade Federal do Pará pelo apoio financeiro ao presente trabalho e à CAPES e ao CNPq pelo incentivo na forma de bolsa de Produtividade em Pesquisa $(\mathrm{CNPq} / \mathrm{PQ})$ para o primeiro autor e de bolsa de mestrado (CAPES) para o terceiro. Aos revisores da RBG pelas sugestões ao manuscrito.

\section{Referências}

Anaisse Jr J., Truckenbrodt W., Rossetti D.F. 2001. Fácies de um sistema estuarino-lagunar no Grupo Itapecuru, área de Açailândia/MA, Bacia do Grajaú. In: D.F. Rossetti, A.M. Góes \& W. Truckenbrodt (eds.) O Cretáceo na Bacia de São Luis - Grajaú.. Museu Paraense Emílio Goeldi, Belém, pp.: 119-150.

Araí M., Uesugui N., Rossetti D.F. \& Góes A.M. 1988. Considerações sobre a idade do Grupo Barreiras no nordeste do estado do Pará. In: SBG, Congr. Bras. Geol., 35, Anais, vol. 2, p. 738-752.

Calaf J.M.C. 2000. Evolução geológica no Cenozóico da região entre Açailândia (MA) e Ligação (PA). Dissertação de Mestrado, Centro de Geociências, UFPa, $112 \mathrm{p}$

Calaf J.M.C., Kotschoubey B. \& Truckenbrodt W. 1999a. Sedimentos siliciclásticas e formações lateríticas do Terciário Superior/Quaternário na região Açailândia-Ligação do Pará, NE do Pará/W do Maranhão. In: SBG/Norte, Simp. Geol. Amaz., 6, Resumos expandidos, p. 359362 .

Calaf J.M.C., Kotschoubey B. \& Truckenbrodt W. 1999b. Evolução da cobertura laterítica/bauxítica na região entre Açailândia (MA) e Ligação do Pará (PA). In: SBG/Norte, Simp. Geol. Amaz., 6, Resumos expandidos, p. 395-398.

Cavalcante L.M. 2000. Neotectônica na área do Tiracambú (NE do estado do Pará, $N W$ do estado do Maranhão). Dissertação de Mestrado, Centro de Geociências, UFPa, 147 p.

Costa M.L. 1991. Aspectos geológicos dos lateritos da Amazônia. Rev.Bras.Geoc., 21:146-160.

Costa J.B.S. \& Hasui Y. 1997. Evolução geológica da Amazônia. In: M.L. Costa \& R.S. Angélica (eds.) Contribuições à Geologia da Amazônia. FINEP, SBG/Norte, pp.: 15-90.

Fernandes J.M.G. 1988. Bioestratigrafia da Formação Pirabas. In: SBG, Congr. Bras. Geol., 35, Anais, vol. 6, p. 2376-2382.

Ferreira C.S. 1982. Notas estratigráficas sobre o Cenozóico marinho do Estado do Pará. In: SBG/NO, Simp. Geol. Amaz., 1, Anais, vol. 1, p. $84-88$. 
Evolução geológica da porção meridional da Província Bauxitífera de Paragominas durante o Neógeno/Pleistoceno (Noroeste da Bacia do Grajaú, nordeste do Pará e extremo oeste do Maranhão)

Ferreira C.S. \& Francisco B.H.R. 1988. As relações da Formação Pirabas (Oligoceno-Mioceno) com as formações continentais terciárias no NE do Pará. In: SBG, Congr. Bras. Geol., 35, Anais, 2:761-764.

Ferreira C.S., Vicalvi M.A. \& Macedo A.C.M. 1984. Os limites meridionais da Bacia de Pirabas, Estado do Pará. In: SBG, Congr. Bras. Geol., 33, Anais, 1:326-329.

Góes A.M. 1981. Estudo sedimentológico dos sedimentos Barreiras, Ipixuna e Itapecuru, no nordeste do Pará e noroeste do Maranhão. Dissertação de Mestrado, Centro de Geociências, UFPa, 55 p.

Góes A.M. 1995. A Formação Poti (Carbonifero inferior) da bacia do Parnaíba. Tese de doutorado, Inst. Geoc., USP, 171 p.

Góes A.M. \& Rossetti D.F. 2001. Gênese da Bacia de São Luis-Grajaú, Meio-Norte do Brasil. In: D.F. Rossetti, A.M. Góes \& W. Truckenbrodt (eds.) O Cretáceo da Bacia de São Luis-Grajaú. Museu Paraense Emílio Goeldi, Belém, pp.: 15-30.

Góes A.M. \& Truckenbrodt W. 1980. Caracterização faciológica e interpretação ambiental dos sedimentos Barreiras na Região Bragantina, nordeste do Pará. In: SBG, Congr. Bras. Geol., 31, Anais, vol. 2, p. 766-771.

Góes A.M., Rossetti D.F. \& Nogueira A.C.R. 1990. Modelo deposicional preliminar da Formação Pirabas no nordeste do estado do Pará. Bol. Mus. Par. Emílio Goeldi. Série Ciências da Terra, 2: 3-15.

Horbe A.M.C. \& Costa M.L 1999. Genetic relationship between lateritic duricrusts and soils in the Amazonian region - Brazil. In: Intern. Geochem. Expl. Symp., Vancouver, Abstracts Volume, p. 123-124.

King L.C. 1967. The morphology of the Earth. Oliver \& Boyd, Edinburgh ( 2 nd ed.), $726 \mathrm{p}$.

Kotschoubey B. \& Truckenbrodt W. 1981. Evolução poligenética das bauxitas do distrito de Paragominas - Açailândia (estados do Pará e Maranhão). Rev. Bras. Geoc., 11:193-202.

Kotschoubey B. \& Truckenbrodt W. 1994. Evidências de bauxitização tardia no nordeste do estado do Pará. In: SBG/Norte, Simp. Geol. Amaz., 4, Anais, p. 269-271.

Kotschoubey B., Truckenbrodt W. \& Hieronymus B. 1987. Phases and zonality of the bauxitic alteration in the northeast of the State of Para (Brazil). Travaux ICSOBA, 16-17:115-127.

Kotschoubey B., Truckenbrodt W. \& Hieronymus B. 1996. Depósitos de caolim e argila semi-flint no nordeste do Pará. Rev. Brás. Geoc., 26:71-80.

Kotschoubey B., Truckenbrodt W. \& Hieronymus B. 1997. Bauxite deposits of Paragominas. In: A. Carvalho, B. Boulangé, A.J. Melfi \& Y. Lucas (eds.) Brazilian Bauxites. USP/FAPESP/ORSTOM, São Paulo, p. 75-106.

Kotschoubey B., Truckenbrodt W. \& Menezes L.A.Q. 1989. Polyphasic origin of the Ipixuna bauxite, northeastern state of Pará, Brazil. Travaux ICSOBA, 19:105-113.

Krook L. 1979. Sediment petrographical studies in Northern Suriname. $\mathrm{PhD}$ Thesis, Vrije Universiteit te Amsterdam, $154 \mathrm{p}$.

Leite F.P.R., Oliveira M.E.B., Araí M. \& Truckenbrodt W. 1997. Palinoestratigrafia da Formação Pirabas e Grupo Barreiras, Mioceno do nordeste do estado do Pará, Brasil. Rev. Univ. Guarulhos, 2: 141147.

Rossetti D.F. 2000. Influence of low amplitude/high frequency relative sea-level changes in a wave-dominated estuary (Miocene), São Luis Basin, northern Brazil. Sedimentary Geology, 133:295-324.

Rossetti D.F. 2001. Late Cenozoic sedimentary evolution in northeastern
Pará, Brazil, within the context of sea level changes. J. South Am. Earth Sci., 14:77-89.

Rossetti D.F. \& Truckenbrodt W. 1999. Nomenclatura estratigráfica de depósitos cretáceos expostos na bacia de São Luís (MA). In: Simp. Cretáceo do Brasil, 5, Boletim UNESP, p. 485-490.

Rossetti D.F., Truckenbrodt W. \& Góes A.M. 1989. Estudo paleoambiental e estratigráfico dos sedimentos Barreiras e Pós-Barreiras na região Bragantina, nordeste do Pará. Bol. Mus. Par. Emilio Goeldi, Série Ciências da Terra, 1:5-74.

Rossetti D.F., Góes A.M. \& Truckenbrodt W. 1990. A influência marinha nos sedimentos Barreiras. Bol. Mus. Par. Emílio Goeldi, Série Ciências da Terra, 2:17-29.

Sá J.H.S. 1969. Contribuição à geologia dos sedimentos terciários e quaternários da região Bragantina, Estado do Pará. Bol. Geol. Inst. Geoc., UFRJ, Rio de Janeiro,3: 21-36.

Santos Jr. A.E. \& Rossetti D.F. 2002. Influência estuarina na Formação Ipixuna, porção média do rio Capim, Sub-bacia de Cametá. In: Simp. Cretáceo do Brasil, 6, Boletim, p. 1-5.

Solymar K. 1969. Alumogoethit in den ungarischen Bauxiten. Ann. Inst. Geol. Publ. Hung. 3:359-373.

Sombroek W.G. 1966. Amazon soils. A reconnaissance of the soils of the Brazilian Amazon region. Wageningen, Holland, 292 p.

Tardy Y. \& Roquin C. 1998. Derive des continents, paleoclimats et altérations tropicales. BRGM, Orléans, France, 473 p.

Théveniaut H. \& Freyssinet Ph. 1999. Paleomagnetism applied to lateritic profiles to assess saprolite and duricrust formation processes: the example of the Mont Baduel profile (French Guiana). Paleogeogr. Paleoclim., Paleoeco., 148:209-231.

Théveniaut H. \& Freyssinet Ph. 2002. Timing of lateritization of the Guiana Shield: synthesis of paleomagnetic results from French Guiana and Suriname. Paleogeogr., Paleoclim., Paleoeco., 178:91-117.

Truckenbrodt W. \& Kotschoubey B. 1981. Argila de Belterra - cobertura terciária das bauxitas amazônicas. Rev. Bras. Geoc., 11:203-208.

Truckenbrodt W. \& Kotschoubey B. 1994. Aspectos petrográficos e geoquímicos de bauxitas na Amazônia oriental. In: SBG/Norte, Simp. Geol. Amaz., 4, Anais, p. 289-290.

Truckenbrodt W., Kotschoubey B. \& Góes A.M. 1982. Considerações a respeito da idade das bauxitas na parte leste da região amazônica. In: SBG/Norte, Simp. Geol. Amaz., 1, Anais, p. 201-209.

Truckenbrodt W., Kotschoubey, B. \& Schellmann W. 1991. Composition and origin of the clay cover on north-brazilian laterites. Geologische Rundschau, 80:591-610.

Urdinínea J.S.A. 1977. Aspectos geoquímicos e ambientais dos calcários da Formação Pirabas - PA. Tese de Doutorado, UFRGS, 198 p.

Vasconcelos P.M., Becker T.A., Renne P.R. \& Brimhall G.H. 1992. Age and duration of weathering by ${ }^{40} \mathrm{~K} /{ }^{40} \mathrm{Ar}$ and ${ }^{40} \mathrm{Ar} /{ }^{39} \mathrm{Ar}$ analysis of potassium-manganese oxides. Science, 258:451-455.

Vasconcelos P.M., Renne P.R., Brimhall G.H. \& Becker T.A. 1994. Direct dating of weathering phenomena by ${ }^{40} \mathrm{Ar}{ }^{39} \mathrm{Ar}$ and $\mathrm{K}-\mathrm{Ar}$ analysis of supergene K-Mn oxides. Geochim. Cosmoch. Acta, 58:1635-1665.

Manuscrito A - 1482

Recebido em 20 de dezembro de 2003

Revisão dos autores em 20 de março de 2005

Revisão aceita 05 de abril de 2005 